\title{
Experimental Workshops in Student Labs and at School - What Influence do Location and Personality Traits have on Learners' Motivational Variables?
}

\author{
Kerstin Röllke ${ }^{1 \star}$, Anna-Lena Maak ${ }^{1}$, Annkathrin Wenzel ${ }^{1}$, Norbert Grotjohann ${ }^{1}$
}

${ }^{1}$ Faculty of Biology, Biology Didactics, Bielefeld University, Bielefeld, GERMANY

*Corresponding Author: kerstin.roellke@uni-bielefeld.de

Citation: Röllke, K., Maak, A.-L., Wenzel, A., \& Grotjohann, N. (2020). Experimental Workshops in Student Labs and at School - What Influence do Location and Personality Traits have on Learners' Motivational Variables?. Pedagogical Research, 5(1), em0050. https://doi.org/10.29333/pr/6338

\section{ARTICLE INFO}

Received: 29 Oct. 2019

Revised: 21 Nov. 2019

Accepted: 21 Nov. 2019

\begin{abstract}
To support science education, more than 350 student labs have been established throughout Germany in the last decades. The goal of these out-of-school facilities is to foster the students' scientific literacy and promote interest in STEM (science, technology, engineering, and mathematics) by providing the students with the opportunity to conduct experiments. Primarily, they are located at universities, other research facilities, or in companies. The present study investigates whether an experimental workshop dealing with DNA in the context of a lab-on-tour model can yield the same motivational outcome in terms of situational interest and flow experience as the same workshop held at a school. 110 high school students participated in the workshop at the authentic biotechnology laboratory teutolab-biotechnologie at Bielefeld University; 177 high school students participated in the workshop, with the same equipment and the same tutors in their biology classrooms at school. The results of (M)ANOVA showed no differences between the groups with respect to the students' perception of the motivational variables (situational interest and flow experience).
\end{abstract}

In addition, the study investigated the influence of personality traits: Individual interest was found to have an impact on situational interest and flow experience. In contrast, gender and a student's biology grade were not found to influence these motivational variables.

In conclusion, an experimental workshop designed for a student lab can be provided as a lab-on-tour model with the same motivational outcome. The professional and technical expertise of specialists in lab work can be used as a valuable support for the educational system.

Keywords: STEM education, student lab, lab-on-tour model, personality traits, individual interest, situational interest, flow

\section{INTRODUCTION}

Since performance studies like PISA or TIMMS revealed deficiencies in the scientific literacy of German students and a deficit in supporting scientifically talented young people, student labs were established to counteract these problems (Haupt \& Hempelmann, 2015). Today, more than 350 of these institutions are spread throughout Germany. They assist the educational system by facilitating learning through lab activities (Euler, 2009). In this way, students' interest and insight in natural sciences is supported (Haupt \& Hempelmann, 2015). This is necessary for two reasons: First, our world is increasingly being shaped by technical inventions which are based on natural science, and thus people need a basic understanding (Rönnebeck, Schöps, Prenzel, Mildner, \& Hochweber, 2010). Second, the job market needs talented newcomers especially in the STEM (science, technology, engineering, and mathematics) area (Nagl, Bargstädt, Hoffmann, \& Müller, 2009; Pfenning, Renn, \& Mack, 2002). Student labs are situated mostly at universities, other research facilities, or in companies. Predominantly, complete class groups visit these institutions within the framework of an excursion. In these so-called classical student labs (Klassische Schülerlabore), they conduct experiments that are in line with the school curriculum (Haupt et al., 2013). Highly talented children can be supported in so-called student research centers (Schülerforschungszentren). Here they can search for answers to their own questions by conducting experiments in their free time in real out-of-school activities (Haupt et al., 2013).

Different studies have shown that student labs promote interest in natural science (Damerau, 2012; Engeln, 2004; Glowinski, 2007; Pawek, 2009; Zehren, 2009). But is this outcome dependent on the new surrounding of an authentic out-of-school lab? And what influence do personality traits have in these learning locations? This study investigates the motivational variables situational 
interest and flow experience of students conducting experiments in the student lab at the university in comparison to students conducting the same experiments in the classroom, taking personality traits additionally into account.

\section{THEORETICAL BACKGROUND}

According to the framework model for structuring pedagogically important components by Krapp (1993), learning motivation is influenced by different conditions: the learning situation and topic, the learner's personality, and the sociocultural environment. Therefore, to examine the goal attainment of student labs which support STEM education, motivational variables like situational interest and flow experience in the learning situation should be investigated as well as personal characteristics.

\section{Interest}

The basic idea behind the concept of interest is that a person is in constant interaction with his or her surroundings (Krapp, 1992) and thus with the learning situation and topic. According to the person-object theory of interest (POI) (Krapp, 2002), interest is the specific relationship between a person and an object. Interest can be analyzed on two levels: On the first level, interest depends on personal (habitual) structures and is called individual interest. An individual occupies himself or herself with a certain object due to a relatively stable tendency to do so. Individual interest has an emotional valence and a value-related valence. On the second level, interest can be caused by a current engagement, an actual learning activity, or any other stimulating situation. This interest, caused by external factors, is called situational interest.

According to the frame model of interest genesis by Krapp (1998), the interaction of an individual with an object leads to situational interest. Under certain conditions, this rather short-term situational interest can be permanently transformed to individual interest by internalization.

Mitchell (1993) further differentiates situational interest into a catch component and a hold component. Although various stimulating situations can catch an individual's interest, empowering individuals, for example, by creating meaningful content, holds their interest for a longer period of time. Linnenbrink-Garcia et al. (2010) were able to show the difference in individual and situational interest by confirmatory factor analysis of a self-report questionnaire and found a three-factor model for situational interest (SI): Triggered situational interest (triggered SI) is generated by the presentation of course material. As it grabs the learners' attention, it is consistent with the catch component described by Mitchell (1993). Analogous to the hold component, they were able to verify the maintained situational interest (maintained SI). Because maintained SI links triggered SI and individual interest, it is somewhat similar to individual interest and can therefore be divided into feeling and value elements (LinnenbrinkGarcia et al., 2010). Maintained SI 'feeling' indicates the learner's feelings caused by the material, maintained SI 'value' represents the quality of the importance of the material.

If a learner reports interest, an internal factor is stimulating the operation. This stimulus, which is located within the action, can be called intrinsic and can be produced not only by the object but also by joy in the action itself (Heckhausen \& Heckhausen, 2009). This aspect will be clarified next.

\section{Flow}

As described previously, dealing with an object always takes place in a certain setting. These situations can be enjoyable or boring. The state of perfect entertainment is described in flow theory by Csikszentmihalyi (1975).

The feeling of flow can be described by different components: Essentially, there is the autotelic nature of flow in which there is no need for a goal or any other external motivation. Furthermore, action and awareness are merging, attention is centered on a limited field, and the person is self-forgetful while remaining in control of his or her actions and the environment. Also, the person is working on a clearly defined task and is receiving unambiguous feedback about his or her actions (Csikszentmihalyi, 1975, pp. 38-48).

A person can attain a state of flow when his or her skills match the demands of the situation or activity perfectly (Csikszentmihalyi, 1975, p. 50). Boredom results when skills are higher than demands. Worry results when demands are higher than skills. In extreme cases, there can be anxiety on both ends of the spectrum (Csikszentmihalyi, 1975, p. 49). Whether an individual assesses skills or demands as higher or evenly matched depends on the individual's perception (Csikszentmihalyi, 1975, p. 50). Therefore, flow is perceived differently by different people.

In conclusion, the demands of the learning situation should fit the skills of the learners to increase the likelihood that the learners experience flow and therefore respond to intrinsic stimulus.

The extent to which these are linked to different personality traits will be discussed next.

\section{Personality Traits}

As mentioned above, individual interest is a personal characteristic. On the one hand, it can be considered the result of the internalization of situational interest. Palmer, Dixon, and Archer (2017) were able to show that regular experiences of situational interest in science-related activities result in higher individual interest in science. On the other hand, the personality trait individual interest can be expected to influence the perception of situational interest. However, Chen and Darst (2002) found only a weak correlation of $r<0.01$ between individual and situational interest. In a microanalytical investigation, Rotgans and Schmidt (2018) were able to show that individual interest only has an influence on the situational interest at the beginning of a task. Glowinski and Bayrhuber (2011) showed that personal characteristics, such as prior individual interest, are significantly interrelated with students' interest in the lab situation. 
Student labs as informal settings should be valuable and joyful for all students. By triggering interest, these labs should support the development of a longer-lasting interest. This should be the case for students of all grades. One factor that predicts school performance is cognitive ability (Rindermann \& Neubauer, 2004), but there may be more factors, such as ability selfperception and intrinsic values (Spinath, Spinath, Harlaar, \& Plomin, 2006). As Goetz, Preckel, Pekrun, and Hall (2007) showed, cognitive ability influences the perception of activity-related emotions: higher cognitive ability leads to higher enjoyment levels, lower cognitive ability leads to higher anger and anxiety levels. Itzek-Greulich and Vollmer (2017) were able to show that cognitive ability is positively correlated with motivational variables like enjoyment, situational interest, and competence. At the same time, in that study, prior knowledge - which should be represented by school grades as well - was a negative predictor: students with more prior knowledge reported less joy and situational interest and more boredom in the theoretical part of a student lab session.

Furthermore, there was a difference with respect to gender, with the female adolescents benefitting: they reported more favorable motivational outcomes in the practical part (Itzek-Greulich \& Vollmer, 2017). However, other studies revealed no gender difference. For example, Heindl and Nader (2018) found in an experimental inquiry-based learning setting that it was equally suitable for boys and girls. Engeln (2004) found no differences in the perception of interest in student lab sessions. These results are remarkable because the PISA study 2015 indicated a decrease in joy and interest regarding natural sciences, especially for female adolescents (Schiepe-Tiska et al., 2016). The gender has an influence on the topics of interest: Male adolescents are more interested in research, dangerous applications in science, physics, and technology, whereas female adolescents are more interested in natural phenomena overall and topics that deal with the body (Holstermann \& Bögeholz, 2007). There are also gender effects regarding experiments, with female adolescents reporting more enjoyment, situational interest, competence, and less negative emotions than male adolescents (Itzek-Greulich \& Vollmer, 2017). Furthermore, the perception of experiments is gender specific. For girls, the social aspect is more important, for boys, the control is reported as being more important (Martinez, 1992).

Thus, in an analysis comparing the impact of an experimental workshop held at a school versus at an authentic laboratory, the present study considers gender, individual interest, and students' individual school grades.

\section{Hypotheses}

Because - in contrast to school - a student lab is an authentic out-of-school environment and should support motivational variables, such as situational interest and flow, which are described as being inherently intrinsic motivational variables, our first two hypotheses are

$\mathrm{H}_{1.1}$ : The level of situational interest that learners report is higher in an experimental workshop held in a student lab than in the classroom at school.

$\mathrm{H}_{1.2}$ : The level of flow that learners report is higher in an experimental workshop held in a student lab than in the classroom at school.

Since individual interest as a learner's personality trait has an impact on situational interest, our next hypotheses are

$\mathrm{H}_{2.1}$ : Students with higher individual interest report a higher level of situational interest in an experimental workshop.

$\mathrm{H}_{2.2}$ : Students with higher individual interest report a higher level of flow in an experimental workshop.

As school grades are - among other things - predicted by cognitive ability, a construct that influences the perception of activity-related emotions, the following hypotheses are

$\mathrm{H}_{3.1}$ : Students with better biology grades report a higher level of situational interest in an experimental workshop.

$\mathrm{H}_{3.2}$ : Students with better biology grades report a higher level of flow in an experimental workshop.

Regarding gender, there are no distinct research findings. Female adolescents' interest in science is less than male adolescents' interest and continues to decrease over time. Yet female adolescents have a higher interest in biology themes and benefit more from experiments. The next hypotheses are

$\mathrm{H}_{4.1}$ : Female adolescents report a higher level of situational interest than male adolescents in an experimental workshop.

$\mathrm{H}_{4.2}$ : Female adolescents report a higher level of flow than male adolescents in an experimental workshop.

\section{MATERIALS AND METHODS}

We developed an experimental workshop in the field of biotechnology because this is an interdisciplinary field that combines molecular biology with aspects of chemistry, technology, and engineering, making it ideal for fostering interest in a broad range of science. High school students performed two methods of DNA extraction, measured the concentration of the DNA, made it visible by gel electrophoresis, and compared both experimental methods. The scientific problem was embedded in the realistic context of bone marrow donation. During the workshops, which lasted four hours, the tutors gave theoretical input via a PowerPoint presentation, discussed with the class, and introduced the instructions for the experiments. The students conducted the experiments in groups of two or three. Each group had their own special equipment, like micropipettes, chemical solutions, and so on. There were central places for the machines which the entire class needed. The tutors for the workshops were two student teachers who had dealt intensively with the contents beforehand. The biology teachers of the classes assumed the role of observers.

287 high school students (Gymnasium, German academic high school) took part in the study ( $M_{\text {age: }} 15.6$ years, $S D_{\text {age: }} 0.8$ years; female: $58.9 \%$, male: $41.1 \%$ ). The treatment group participated in the workshop in the authentic laboratory teutolab- 
biotechnologie at Bielefeld University ( $n=110$ students); the control group participated in the same workshop in the biology classrooms at school ( $n=177$ students).

To investigate the interest of the students, scales from Linnenbrink-Garcia et al. (2010) were used. The Situational Interest Scale consists of the three subscales triggered SI, maintained SI 'feeling' and maintained SI 'value' (see chapter Theoretical Background, Interest). Using factor analysis, Linnenbrink-Garcia et al. (2010) showed that each scale represents an independent dimension, yet the scales are related. The scale for measuring individual interest comprises eight items. Table 1 shows the scales, the reliability, and sample items. The questionnaire with 18 items overall was completed by the students at the end of the workshop, after about four hours. To investigate the students' flow experience, a scale from Rheinberg, Vollmeyer, and Engeser (2003) was used. They explore the construct with ten items that have a high internal consistency, which means that it can be applied one-dimensionally. In addition to the scale, Rheinberg et al. (2003) provide three items for students to assess their own skills and the demanded skills in the workshop. As described in chapter Theoretical Background, Flow, flow requires that an action's demands fit a person's skills. Moreover, these items provide valuable feedback to the creator of the workshop about how participants rate the complexity. The questionnaire was completed by the students during the workshop, after about three hours, while the students were waiting during an incubation step. Table 1 shows these separately examined items and a sample item from the flow scale, including the reliability.

Table 1. Example items and reliabilities (Cronbach's alpha) for the interest and flow scales as well as items for the assessment questions

\begin{tabular}{|c|c|c|}
\hline Scale/Subscale & Example item & Reliability \\
\hline Individual interest (total) & I like STEM sciences. & 0.85 \\
\hline Situational interest (total) & & 0.88 \\
\hline Triggered SI & The workshop was entertaining. & 0.71 \\
\hline Maintained SI 'feeling' & I enjoyed the workshop. & 0.78 \\
\hline Maintained SI 'value' & What I did during the workshop is important to me. & 0.68 \\
\hline Flow (total) & My thoughts and activities are fluid and smooth. & 0.70 \\
\hline Assessment & Item & \\
\hline Comparison of activities & Compared to what I otherwise do, the current activity is ... & \\
\hline Evaluation of requirements & For me personally, the current requirements are ... & \\
\hline Evaluation of one's own skills & I think my skills in this field are ... & \\
\hline
\end{tabular}

The items from the interest scales and the flow scales were answered on a five-point Likert scale from 1 ('I don't agree') to 5 ('I completely agree'). The assessment items had a five-point scale as well, ranging from 1 ('low') to 5 ('high'), 1 ('too low') to 5 ('too high'), and 1 ('easy') to 5 ('difficult').

Figure 1 shows the design of the study. The means of the subscales were tested for statistically significant differences by performing a MANOVA for the situational interest overall and an ANOVA for the subscales of the interest scale, the flow scale, and the assessment items. In the case of more than two groups, the post-hoc test 'Tukey HSD' was conducted. The effect sizes are judged according to Cohen (1988, p. 83): As $\eta^{2}$ and $r^{2}$ are identical, $r^{2}=0.01$ is a small effect, $r^{2}=0.09$ is a medium effect, and $r^{2}=0.25$ is a high effect. All statistical analyses were performed using SPSS.

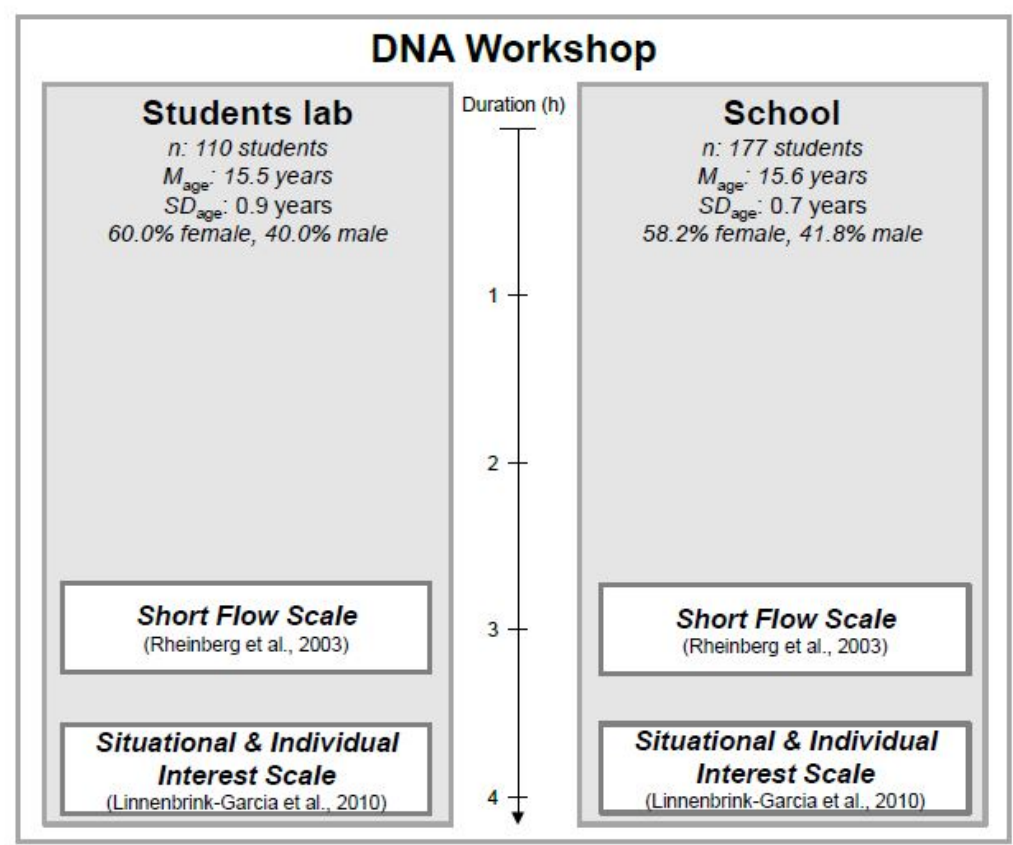

Figure 1. Design of the study comparing students' flow experience and situational interest in an experimental workshop held in the student lab and at school 
To analyze the influence of individual interest and biology grades as personality traits, the interval scaled variables were converted into nominal variables by creating categories. This process was done in orientation on the distributions of the characteristics. The groups were divided into three parts (tertiles) to form groups at the highest level, the middle level, and the lowest level.

\section{RESULTS}

The results will be shown for each hypothesis and examined separately for the influence of the treatment, individual interest, biology grade, and gender.

\section{Influence of the Treatment}

First, the individual interest and the biology grade were explored to evaluate the equal distribution of these personality traits on the groups 'student lab' and 'school'. As a mandatory requirement, there was no significant difference. Hence any potential differences in the situational interest, the flow experience, and the assessment between the groups could be attributed to the treatment.

The ANOVA showed no significant differences between the groups. The results of the influence of the treatment on situational interest and its subscales, flow, and the assessment items are shown in Table 2.

Table 2. Influence of the treatment on situational interest and its subscales, flow, and the assessment items (teutolab: $n=110$; school: $n=177)$

\begin{tabular}{|c|c|c|c|c|c|}
\hline & $\begin{array}{c}\text { teutolab } \\
M(S D)\end{array}$ & $\begin{array}{l}\text { school } \\
M(S D)\end{array}$ & F-Value & $p$-Value & $\eta^{2}$ \\
\hline Situational interest (total) & $3.64(0.62)$ & $3.57(0.68)$ & 0.97 & 0.41 & 0.00 \\
\hline $\begin{array}{c}\text { Triggered SI } \\
\end{array}$ & $3.85(0.64)$ & $3.80(0.70)$ & 0.34 & 0.56 & 0.00 \\
\hline Maintained SI 'feeling' & $3.70(0.68)$ & $3.68(0.80)$ & 0.03 & 0.86 & 0.00 \\
\hline Maintained SI 'value' & $3.37(0.96)$ & $3.22(0.82)$ & 2.04 & 0.16 & 0.01 \\
\hline Flow (total) & $3.74(0.53)$ & $3.80(0.55)$ & 0.86 & 0.35 & 0.00 \\
\hline \multicolumn{6}{|l|}{ Assessment } \\
\hline Comparison of activities & $1.92(0.90)$ & $2.19(0.92)$ & 2.57 & 0.11 & 0.01 \\
\hline Evaluation of requirements & $2.41(0.72)$ & $2.51(0.75)$ & 1.23 & 0.27 & 0.00 \\
\hline Evaluation of one's own skills & $3.55(0.76)$ & $3.53(0.88)$ & 0.05 & 0.82 & 0.00 \\
\hline
\end{tabular}

There were no interaction effects between the treatment and individual interest, biology grades, and gender, except for two combinations: first, students with lower individual interest feel less flow in the lab than at school, and second, male adolescents assess the activities at school as more challenging compared to their daily activities.

\section{Influence of the Individual Interest}

The individual interest significantly influenced situational interest in each subscale, flow experience, and two of the three assessment items. The higher the individual interest, the higher was triggered SI, maintained SI 'feeling', maintained SI 'value', and the flow level. The post-hoc test showed significant differences between each of the tertiles and therefore indicated constant progress. The effect size can be described as low. The results of the influence of the individual interest on situational interest and its subscales, flow, and the assessment items are shown in Table 3.

Table 3. Influence of individual interest on situational interest and its subscales, flow, and the assessment items (1st Tertile $n=102$, 2nd Tertile $n=99,3$ rd Tertile $n=88$ )

\begin{tabular}{|c|c|c|c|c|c|c|}
\hline & $\begin{array}{c}\text { 1st Tertile } \\
M(S D)\end{array}$ & $\begin{array}{c}\text { 2nd Tertile } \\
\qquad M(S D)\end{array}$ & $\begin{array}{c}\text { 3rd Tertile } \\
M(S D)\end{array}$ & F-Value & $p$-Value & $\eta^{2}$ \\
\hline Situational interest (total) & $3.89(0.57)$ & $3.59(0.65)$ & $3.26(0.59)$ & 10.30 & 0.00 & 0.10 \\
\hline $\begin{array}{c}\text { Triggered SI } \\
\end{array}$ & $4.03(0.63)$ & $3.78(0.66)$ & $3.62(0.69)$ & 9.10 & 0.00 & 0.06 \\
\hline Maintained SI 'feeling' & $4.01(0.65)$ & $3.69(0.73)$ & $3.30(0.71)$ & 24.87 & 0.00 & 0.15 \\
\hline Maintained SI ‘value’ & $3.63(0.72)$ & $3.30(0.99)$ & $2.85(0.72)$ & 21.23 & 0.00 & 0.13 \\
\hline Flow (total) & $3.97(0.49)$ & $3.78(0.47)$ & $3.55(0.59)$ & 15.67 & 0.00 & 0.10 \\
\hline \multicolumn{7}{|l|}{ Assessment } \\
\hline Comparison of activities & $2.01(0.93)$ & $1.96(0.92)$ & $2.13(0.90)$ & 0.80 & 0.45 & 0.01 \\
\hline Evaluation of requirements & $2.29(0.82)$ & $2.52(0.68)$ & $2.62(0.67)$ & 5.09 & 0.01 & 0.04 \\
\hline Evaluation of one's own skills & $3.88(0.82)$ & $3.51(0.68)$ & $3.17(0.85)$ & 19.26 & 0.00 & 0.12 \\
\hline
\end{tabular}

Significant values highlighted in grey

\section{Influence of the Biology Grade}

The biology grade was found to influence the interest. Specifically, the individual interest as a personality trait is different, with a medium effect size: the better the biology grades, the higher the individual interest. The maintained SI 'value' differs significantly in the same way, but the effect size is small. The post-hoc test just shows a difference between the lowest and the highest tertile. There are no significant differences in triggered SI, maintained SI 'feeling', and the flow experience. 
In the evaluation of one's own skills, the students with better grades report higher values than the students in the lower tertiles. This difference is significant, with a medium effect size: the post-hoc test shows that just the lowest tertile reports significantly lower means than the other tertiles; the difference between the highest and the medium tertile is not significant. The responses to this item ranged from "skills in this field are ...low (1)" to "...high (5)". The means between 3.22 and 3.88 show that the students tend to evaluate their own skills as more high than low.

In the evaluation of the workshop requirements, there is a significance the other way around, with a low effect size: here, the higher the tertile is, the lower the values. The answers to this item ranged from "...the requirements were ... too low (1)" to "...too high (5)", so (3) was equivalent to "adequate". The means in all tertiles were under 3 (ranging from 2.33 to 2.58), and the lowest tertile was closest to adequate requirements.

In the assessment item about the comparison with other activities, there were no significant differences. The responses to this item ranged from "...the current activity is ...easy (1)" to "...difficult (5)". The means between 1.91 and 2.13 show that the students tend to evaluate the experimental workshops as more easy than difficult.

The results of the biology grade's influence on individual interest, situational interest and its subscales, flow, and the assessment items are shown in Table 4.

Table 4. Influence of biology grade on individual interest, situational interest and its subscales, flow, and the assessment items (1st Tertile $n=72$, 2nd Tertile $n=102$, 3rd Tertile $n=113$ )

\begin{tabular}{|c|c|c|c|c|c|c|}
\hline & $\begin{array}{c}\text { 1st Tertile } \\
M(S D)\end{array}$ & $\begin{array}{c}\text { 2nd Tertile } \\
M(S D)\end{array}$ & $\begin{array}{c}\text { 3rd Tertile } \\
M(S D)\end{array}$ & F-Value & $p$-Value & $\eta^{2}$ \\
\hline Individual interest (total) & $4.07(0.79)$ & $3.80(0.87)$ & $3.46(0.87)$ & 11.78 & 0.00 & 0.08 \\
\hline Situational interest (total) & $3.76(0.64)$ & $3.58(0.60)$ & $3.51(0.70)$ & 1.58 & 0.15 & 0.02 \\
\hline Triggered SI & $3.94(0.61)$ & $3.77(0.66)$ & $3.78(0.73)$ & 1.55 & 0.22 & 0.01 \\
\hline Maintained SI 'feeling' & $3.82(0.80)$ & $3.68(0.68)$ & $3.60(0.77)$ & 1.74 & 0.18 & 0.01 \\
\hline Maintained SI 'value’ & $3.51(0.73)$ & $3.27(0.76)$ & $3.14(1.03)$ & 3.94 & 0.02 & 0.03 \\
\hline Flow (total) & $3.85(0.49)$ & $3.79(0.53)$ & $3.72(0.58)$ & 1.37 & 0.26 & 0.01 \\
\hline \multicolumn{7}{|l|}{ Assessment } \\
\hline Comparison of activities & $2.06(0.99)$ & $2.14(0.92)$ & $1.91(0.85)$ & 1.68 & 0.19 & 0.01 \\
\hline Evaluation of requirements & $2.31(0.74)$ & $2.46(0.70)$ & $2.58(0.75)$ & 3.20 & 0.04 & 0.02 \\
\hline Evaluation of one's own skills & $3.88(0.79)$ & $3.65(0.79)$ & $3.23(0.80)$ & 15.93 & 0.00 & 0.10 \\
\hline
\end{tabular}

Significant values highlighted in grey

\section{Influence of Gender}

The Gender has an influence on interest. The individual interest as a personality trait is higher in male adolescents than in female adolescents, with a low effect size. The maintained SI 'value' differs in the other direction. Female adolescents demonstrate higher values than male adolescents, with a small effect size. There are no significant differences in triggered SI, maintained SI 'feeling', the flow experience, and all items referring to the assessment. There is a slight tendency for female adolescents to report higher triggered SI and flow experience levels. The results of the influence of gender on individual interest, situational interest and its subscales, flow, and the assessment items are shown in Table 5.

Table 5. Influence of gender on individual interest, situational interest and its subscales, flow, and the assessment items (female: $n=169$, male: $n=118$ )

\begin{tabular}{|c|c|c|c|c|c|}
\hline & $\begin{array}{c}\text { female } \\
M(S D) \\
\end{array}$ & $\begin{array}{c}\text { male } \\
M(S D) \\
\end{array}$ & F-Value & $p$-Value & $\eta^{2}$ \\
\hline Individual interest (total) & $3.62(0.91)$ & $3.89(0.82)$ & 6.21 & 0.01 & 0.02 \\
\hline Situational interest (total) & $3.64(0.65)$ & $3.53(0.66)$ & 2.43 & 0.07 & 0.03 \\
\hline Triggered SI & $3.86(0.66)$ & $3.76(0.70)$ & 1.50 & 0.22 & 0.01 \\
\hline Maintained SI 'feeling' & $3.70(0.78)$ & $3.67(0.72)$ & 0.10 & 0.76 & 0.00 \\
\hline Maintained SI 'value' & $3.37(0.91)$ & $3.15(0.83)$ & 4.29 & 0.04 & 0.02 \\
\hline Flow (total) & $3.82(0.54)$ & $3.71(0.54)$ & 2.79 & 0.10 & 0.01 \\
\hline \multicolumn{6}{|l|}{ Assessment } \\
\hline Comparison of activities & $1.97(0.90)$ & $2.11(0.94)$ & 1.62 & 0.20 & 0.01 \\
\hline Evaluation of requirements & $2.53(0.71)$ & $2.38(0.77)$ & 2.94 & 0.09 & 0.01 \\
\hline Evaluation of one's own skills & $3.52(0.73)$ & $3.57(0.97)$ & 0.22 & 0.64 & 0.00 \\
\hline
\end{tabular}

Significant values highlighted in grey

\section{DISCUSSION}

Students who participate in an experimental workshop at school report the same situational interest and the same flow experience as students who participate in the experimental workshop in a student lab. This is remarkable because the ambience in the student lab is different than the ambience at school because the lab is located within an authentic research center at the university. The specific surroundings in student labs have been found by Brown, Collin, and Duguid (1989) to have an influence. 
Student labs offer the opportunity for students to conduct experiments out of the school context and therefore make authentic science accessible to students (Lee \& Butler, 2003). Collins, Brown, and Newman (1989) suggest supporting students' participation in ordinary practice of the culture by cognitive apprenticeship. In this approach, experts introduce laypersons to their field of work (Collins et al., 1989). The workshop offered in this study was following this approach. Our results show that it is possible to transfer the concept to a school setting successfully. The laboratory equipment and the tutors were the same in both places. The experiments dealing with DNA were ambitious and needed high-price equipment and chemicals that are not available at school. The tutors were experts who were prepared by training and offered specialist knowledge and practical experience with hands-on activities. Teachers are not able to conduct specialized experiments like that, but they wish to include them more in their schools (Fränkel, 2019, pp. 136-175). Until now, there have been no studies that explicitly compare the motivational outcome induced by performing exactly the same experiments and contents with students at different locations. Scharfenberg and Klautke (2003) showed that the acceptance of an authentic lab at university is very high, regardless of whether the lab involves a hands-on experiment or is just theoretical. Huwer (2015) argued that a lab-on-tour model in the field of scientific-technical environmental education improves the current motivation and the knowledge of students, especially in younger classes with students aged about 10 to 12 years, but for older classes with students aged about 14 to 15 years, the authentic lab situation at a university was more important.

In the present study, an experimental workshop was held as a lab-on-tour model as well as in a student lab with equal success. The congruence of skills and requirements as condition for the development of flow was assessed by three items that were rated by the students as fitting relatively well. The learners reported high levels of flow and situational interest and experience in both environments, and thus the workshop can be rated as helpful for fostering biology education. For conducting these kinds of experiments, it is not necessary for classes to leave their schools if a student lab offers to bring the experiment along with the equipment and tutors to the schools. This can be helpful for schools because excursions can sometimes represent serious barriers in daily school life due to organizational and financial challenges. If the student lab operators would expand their offerings by establishing on-tour models, they could make their expertise accessible to more students and enhance the students' interest in science. In each case, a review should be done to determine whether the workshop is suitable for mobile usage and whether the students would benefit from an authentic student lab for other reasons. For example, experiments with genetically modified bacteria are only allowed in labs with safety levels. Also, career guidance could perhaps be better supported at a university.

In addition to the effect of the location, the influence of the personality traits individual interest, biology grade, and gender on motivational variables was investigated. The individual interest of a student has an impact with low effect sizes. The study shows that the individual interest has a general influence on intrinsic motivational variables (situational interest and flow).

Surprisingly, the experimental workshops promote both the situational interest and the flow experience of the students relatively independent of biology grades: In the first instance, students in higher tertiles have higher individual interest, with medium effect sizes. But apart from this influence, there are no differences in the total scale of situational interest and flow. Supporting students equally regardless of biology grade seems to turn out well in the experimental workshop. Regarding the subscales, the maintained SI 'value' is significantly higher depending on higher individual interest. This result indicates that this subscale is more closely related to individual interest than the subscale-maintained SI 'feeling'. In line with theory, it seems logical that the value for an object is more persistently developed than the feeling towards that object. Regarding the triggered SI, the results indicate the same: triggering learners' interest should be less affected by individual interest.

It is also remarkable that the motivational variables in our study are promoted independently of gender. The findings in gender are parallel to the findings with respect to biology grades: there is no significant difference in the situational interest and the flow experience of female and male adolescents, although male adolescents have a higher individual interest. So the experimental workshop could help to close the gender gap, which is in line with other studies (Brandt, 2005; Damerau, 2012; Pawek, 2009; Röllke, 2019) and thus with the goals of student labs to support newcomers in the field of STEM (Haupt \& Hempelmann, 2015). The results for the subscales of situational interest are the same as for biology grades and show the stable character of the maintained SI 'value'.

We conclude that an experimental workshop, whether held in a student lab or at school, can foster an interest in science independently of the location and personality traits. The concept of using these kinds of supplementary learning facilities could be applied more often worldwide, as is already done in other countries such as Luxembourg (John \& Krüger, 2017), Hungary (Domonkos, 2016), and Great Britain (Moss, 2015). Cooperations with German student labs are possible as well (Herbers \& KohseHöinghaus, 2013).

\section{REFERENCES}

Brandt, A. (2005). Förderung von Motivation und Interesse durch außerschulische Experimentierlabors. Göttingen: Cuvillier Verlag.

Brown, J. S., Collin, A., \& Duguid, P. (1989). Situated Cognition and the Culture of Learning. Educational Researcher, 18(1), 32-42. https://doi.org/10.3102/0013189X018001032

Chen, A., \& Darst, P. W. (2002). Individual and Situational Interest: The Role of Gender and Skill. Contemporary Educational Psychology, 27(2), 250-269. https://doi.org/10.1006/ceps.2001.1093

Cohen, J. (1988). statisTical Power Analysis for the Behavioral Sciences. Hillsdale, NJ: Lawrence Erlbaum Associates. https://doi.org/10.4324/9780203771587 
Collins, A., Brown, J. S., \& Newman, S. E. (1989). Cognitive Apprenticeship: Teaching the Crafts of Reading, Writing, and Mathematics. In L. B. Resnick (Ed.), Knowing, learning, and instruction: Essays in honor of Robert Glaser (pp. 453-494). Hillsdale, $\mathrm{NJ}$ : Erlbaum.

Csikszentmihalyi, M. (1975). Beyond boredom and anxiety. The Jossey-Bass behavioral science series. San Francisco u.a: JosseyBass. Retrieved from http://www.loc.gov/catdir/enhancements/fy0607/76007234-b.html

Damerau, K. (2012). Molekulare und Zell-Biologie im Schülerlabor - Fachliche Optimierung und Evaluation der Wirksamkeit im BeLL Bio (Bergisches Lehr-Lern-Labor Biologie) (Dissertation). Bergische Universität Wuppertal. Retrieved from http://elpub.bib.uniwuppertal.de/servlets/DerivateServlet/Derivate-3530/dc1231.pdf

Domonkos, M. (2016). Schülerlabornetz Ungarn. LeLamagazin, (14), 2-4.

Engeln, K. (2004). Schülerlabors: authentische, aktivierende Lernumgebungen als Möglichkeit, Interesse an Naturwissenschaften und Technik zu wecken. Berlin: Logos Verlag.

Euler, M. (2009). Schülerlabore in Deutschland: Zum Mehrwert authentischer Lernorte in Forschung und Entwicklung. Praxis der Naturwissenschaften / Physik in der Schule, 58(4), 5-9.

Fränkel, S. (2019). Beliefs von Lehrkräften zu inklusiver Begabungsförderung im Biologieunterricht (Dissertation). Universität Bielefeld. https://doi.org/10.4119/UNIBI/2936526

Glowinski, I. (2007). Schülerlabore im Themenbereich Molekularbiologie als Interesse fördernde Lernumgebung (Dissertation). Christian-Albrechts-Universität zu Kiel. Retrieved from https://macau.uni-kiel.de/receive/dissertation_diss_00002564? lang=de

Glowinski, I., \& Bayrhuber, H. (2011). Student labs on a university campus as a type of out-of-school learning environment: Assessing the potential to promote students' interest in science. International Journal of Environmental \& Science Education, 6(4), 371-392. Retrieved from https://eric.ed.gov/?id=EJ959426

Goetz, T., Preckel, F., Pekrun, R., \& Hall, N. C. (2007). Emotional experiences during test taking: Does cognitive ability make a difference? Learning and Individual Differences, 17(1), 3-16. https://doi.org/10.1016/j.lindif.2006.12.002

Haupt, O. J., \& Hempelmann, R. (2015). Eine Typensache! In LernortLabor - Bundesverband der Schülerlabore e.V. (Ed.), Schülerlabor-Atlas 2015: Schülerlabore im deutschsprachigen Raum (pp. 14-21). Stuttgart: Klett MINT.

Haupt, O. J., Domjahn, J., Martin, U., Skiebe-Corrette, P., Vorst, S., Zehren, W., \& Hempelmann, R. (2013). Schülerlabor Begriffsschärfung und Kategorisierung. MNU, 66(6), 324-330.

Heckhausen, J., \& Heckhausen, H. (2009). Motivation und Handeln: Einführung und Überblick. In J. Heckhausen \& H. Heckhausen (Eds.), Motivation und Handeln (pp. 1-9). Heidelberg: Springer. https://doi.org/10.1007/978-3-642-12693-2_1

Heindl, M., \& Nader, M. (2018). The Tendency and Preferred Purposes of Use of Technology by Boys and Girls, and the Production of a Successful Product in an Experimental Inquiry-based Learning Setting with the Use of Digital Technologies. International Journal of Environmental \& Science Education, 13(5), 441-455. Retrieved from http://www.ijese.net/makale/2056

Herbers, R., \& Kohse-Höinghaus, K. (2013). teutolab international. LeLamagazin, (7), 10-11.

Holstermann, N., \& Bögeholz, S. (2007). Interessen von Jungen und Mädchen an naturwissenschaftlichen Themen am Ende der Sekundarstufe I. Zeitschrift für Didaktik der Naturwissenschaften, 13, 71-86.

Huwer, J. (2015). Nachhaltigkeit + Chemie im Schülerlabor: Forschendes Experimentieren im Kontext einer naturwissenschaftlichtechnischen Umweltbildung (Dissertation). Universität des Saarlandes, Saarbrücken. Retrieved from https://publikationen.sulb.uni-saarland.de/handle/20.500.11880/23098

Itzek-Greulich, H., \& Vollmer, C. (2017). Emotional and motivational outcomes of lab work in the secondary intermediate track: The contribution of a science center outreach lab. Journal of Research in Science Teaching, 54(1), 3-28. https://doi.org/10.1002/tea.21334

John, E., \& Krüger, M. (2017). Scienteens Lab - De Labo fir Jonker. LeLamagazin, (18), 9. Retrieved from http://www.lelamagazin.de/download/LeLa.magazin.No18.pdf

Krapp, A. (1992). Interesse, Lernen und Leistung: Neue Forschungsansätze in der Pädagogischen Psychologie. Zeitschrift für Pädagogik, 38(5), 747-770.

Krapp, A. (1993). Die Psychologie der Lernmotivation. Perspektiven der Forschung und Probleme ihrer pädagogischen Rezeption. Zeitschrift für Pädagogik, 39(2), 187-206.

Krapp, A. (1998). Entwicklung und Förderung von Interessen im Unterricht. Psychologie, Erziehung, Unterricht, 44, 185-201.

Krapp, A. (2002). Structural and dynamic aspects of interest development: theoretical considerations from an ontogenetic perspective. Learning and Instruction, 12, 383-409. https://doi.org/10.1016/S0959-4752(01)00011-1

Lee, H.-S., \& Butler, N. (2003). Making authentic science accessible to students. International Journal of Science Education, 25(8), 923-948. https://doi.org/10.1080/09500690305023

Linnenbrink-Garcia, L., Durik, A. M., Conley, A. M., Barron, K. E., Tauer, J. M., Karabenick, S. A., \& Harackiewicz, J. M. (2010). Measuring Situational Interest in Academic Domains. Educational and Psychological Measurement, 70(4), 647-671. https://doi.org/10.1177/0013164409355699

Martinez, M. E. (1992). Interest Enhancement to Science Experiments: Interactions with Student Gender. Journal of Research in Science Teaching, 29(2), 167-177. https://doi.org/10.1002/tea.3660290206 
Mitchell, M. (1993). Situational Interest: Its Multifaceted Structure in the Secondary School Mathematics Classroom. Journal of Educational Psychology, 85(3), 424-436. https://doi.org/10.1037/0022-0663.85.3.424

Moss, A. (2015). Schülerlabore in the UK. LeLamagazin, (12), 5-6. Retrieved from http://www.lelamagazin.de/download/LeLa.magazin.No12.pdf

Nagl, M., Bargstädt, H.-J., Hoffmann, M., \& Müller, N. (Eds.) (2009). Zukunft Ingenieurwissenschaften - Zukunft Deutschland: Beiträge einer 4ING-Fachkonferenz und der ersten Gemeinsamen Plenarversammlung der 4ING-Fakultätentage am 14. und 15.07.2008 an der RWTH Aachen. Berlin, Heidelberg: Springer. https://doi.org/10.1007/978-3-540-89609-8

Palmer, D., Dixon, J., \& Archer, J. (2017). Using Situational Interest to Enhance Individual Interest and Science-Related Behaviours. Research in Science Education, 47(4), 731-753. https://doi.org/10.1007/s11165-016-9526-x

Pawek, C. (2009). Schülerlabore als interessefördernde außerschulische Lernumgebungen für Schülerinnen und Schüler aus der Mittel- und Oberstufe (Dissertation). Christian-Albrechts-Universität zu Kiel. Retrieved from https://macau.unikiel.de/receive/dissertation_diss_00003669

Pfenning, U., Renn, O., \& Mack, U. (2002). Zur Zukunft technischer und naturwissenschaftlicher Berufe: Strategien gegen den Nachwuchsmangel. Stuttgart: Akademie für Technikfolgenabschätzung in Baden-Württemberg.

Rheinberg, F., Vollmeyer, R., \& Engeser, S. (2003). Die Erfassung des Flow-Erlebens. In J. Stiensmeier-Pelster \& F. Rheinberg (Eds.), Diagnostik von Motivation und Selbstkonzept: Test und Trends N. F. Band 2 (pp. 261-279). Göttingen: Hogrefe.

Rindermann, H., \& Neubauer, A. C. (2004). Processing speed, intelligence, creativity, and school performance: Testing of causal hypotheses using structural equation models. Intelligence, 32(6), 573-589. https://doi.org/10.1016/j.intell.2004.06.005

Röllke, K. (2019). Was kann ein Schülerlabor leisten? Konzeptionierung des Schülerlabors teutolab-biotechnologie als Lehr-LernLabor mit Angeboten zur Breiten- und zur Begabtenförderung von Schülerinnen und Schülern (Dissertation). Universität Bielefeld. https://doi.org/10.4119/UNIBI/2935577

Rönnebeck, S., Schöps, K., Prenzel, M., Mildner, D., \& Hochweber, J. (2010). Naturwissenschaftliche Kompetenz von PISA 2006 bis PISA 2009. In E. Klieme, C. Artelt, J. Hartig, N. Jude, O. Köller, M. Prenzel, . . P. Stanat (Eds.), PISA 2009 - Bilanz nach einem Jahrzehnt: Zusammenfassung (pp. 177-198). Münster,

Rotgans, J. I., \& Schmidt, H. G. (2018). How individual interest influences situational interest and how both are related to knowledge acquisition: A microanalytical investigation. The Journal of Educational Research, 111(5), 530-540. https://doi.org/10.1080/00220671.2017.1310710

Scharfenberg, F.-J., \& Klautke, S. (2003). Das Demonstrationslabor Bio-/Gentechnik der Universität Bayreuth: Aufbau und Evaluation. Erkenntnisweg Biologiedidaktik, 2, 25-46. Retrieved from https://www.bcp.fuberlin.de/biologie/arbeitsgruppen/didaktik/Erkenntnisweg/2003/2003_02_Scharfenberg.pdf

Schiepe-Tiska, A., Rönnebeck, S., Schöps, K., Neumann, K., Schmidtner, S., Parchmann, I., \& Prenzel, M. (2016). Naturwissenschaftliche Kompetenz in PISA 2015 - Ergebnisse des internationalen Vergleichs mit einem modifizierten Testansatz. In K. Reiss, C. Sälzer, A. Schiepe-Tiska, E. Klieme, \& O. Köller (Eds.), PISA 2015: Eine Studie zwischen Kontinuität und Innovation (pp. 133-176). Münster, New York: Waxmann.

Spinath, B., Spinath, F. M., Harlaar, N., \& Plomin, R. (2006). Predicting school achievement from general cognitive ability, selfperceived ability, and intrinsic value. Intelligence, 34(4), 363-374. https://doi.org/10.1016/j.intell.2005.11.004

Zehren, W. (2009). Forschendes Experimentieren im Schülerlabor (Dissertation). Universität des Saarlandes, Saarbrücken. Retrieved from https://publikationen.sulb.uni-saarland.de/handle/20.500.11880/22651 